\title{
Unheated and Minimally Heated Winter Greenhouse Production of Specialty Cut Flowers
}

\author{
Todd J. Cavins, ${ }^{1}$ \\ John M. Dole, ${ }^{2}$ and \\ Vicki Stamback ${ }^{3}$
}

\begin{abstract}
Additional index WORds. A nemone, Antirrhinum, snapdragon, Consolida, larkspur, D elphinium, H elianthus sunflower, Lupinus, lupine, Matthida, stock, Viola, pansy
\end{abstract}

Summary. Anemone (A nemone coronaria L.), snapdragon (Antirrhinum majus L. ), larkspur [C onsolida ambigua (L.) P.W. Ball \& H eyw.], delphinium ( $D$ elphinium $\times$ cultorum Voss.), sunflower (H elianthusannuus L.), lupine (Lupi nushartwegi i L indl.), stock [Matthi ola incana (L.) R. Br.], and pansy (Viola $\times$ wittrockiana G ams.) were grown in raised sandy loam ground beds in double-layered polyethylene-covered greenhouses which were either unheated (ambient) or had a $55^{\circ} \mathrm{F}\left(13^{\circ} \mathrm{C}\right)$ minimum night temperature in year 1 and 36 or $50{ }^{\circ} \mathrm{F}\left(2\right.$ or $10^{\circ} \mathrm{C}$ ) minimum night temperature in year 2 . R esults were species specific; however, the extreme low temperatures $\left[21^{\circ} \mathrm{F}\left(-6^{\circ} \mathrm{C}\right)\right]$ in the unheated house limited delphinium and lupine production. The warmest greenhouses ( 55 and $50{ }^{\circ} \mathrm{F}$ ) reduced production time for anemone, delphinium, larkspur, lupine (year 2), snapdragon (year 2),

D epartment of $\mathrm{H}$ orticulture and $\mathrm{L}$ andscape Architecture, O klahomaStateU niversity, Stillwater, O K 740786027.

Approved for publication by the Director, O klahoma Agricultural Experiment Station (OAES). O ur research was supported in part by Sustainable Agriculture Research and Education Program (SARE), Bear Creek Farms, and OAES under project $\mathrm{H}-2119$.

${ }^{1} \mathrm{G}$ raduate research assistant, currently at $\mathrm{D}$ epartment of $\mathrm{H}$ orticultural Science, $\mathrm{N}$ orth $\mathrm{C}$ arolina State U niversity, Box 7609, Raleigh, NC 27695-7609.

${ }^{2}$ Professor, currently at Department of $\mathrm{H}$ orticultural Science, N orth Carolina State U niversity, Box 7609 Raleigh, N C 27695-7609.

${ }^{3} \mathrm{O}$ wner of Bear Creek Farms, Stillwater, OK. 
stock, and sunflower. The coolest greenhouses (unheated and $36^{\circ} \mathrm{F}$ ) increased stem lengths for anemone (year 2), delphinium, larkspur (year 1), lupine (year 2), snapdragon, stock, and sunflower. The coolest greenhouses also yielded a profit or lower net loss for all species except delphinium, lupine, and snapdragon (year 2) for which profits were highest or net losses were lowest in the warmest greenhouses.

$\mathrm{T}$ he peak outdoor specialty cut flower marketing season of September through M ay does not match the typical outdoor production season of $M$ ay through September in the southern $\mathrm{G}$ reat Plains (F. A rnosky, personal communication). Field producers could increase gross sales by expanding to a year-round growing season encompassing high sales holidays such as $V$ alentine's $D$ ay, Easter, and M other's D ay.

Although the growing season could be extended using heated greenhouses, heating expenses can be prohibitive. H owever, unheated or minimally heated greenhouses could profitably provideseason extension for specialty cut flower producers. Winter conditions in the so uthern $G$ reat Plains are typically favorable for low heating expenses due to high light intensity and warm day temperatures. D uring the day, the greenhouse soil is heated by the sun which helps maintain night air temperatures above outdoor night air temperatures.

A number of specialty cuts can be grown at cool temperatures. Anemone yields the highest number and quality of flowers when produced at 41 to 50 ${ }^{\circ} \mathrm{F}\left(5\right.$ to $\left.10^{\circ} \mathrm{C}\right)$ night and 57 to $65^{\circ} \mathrm{F}$ (14 to $18^{\circ} \mathrm{C}$ ) day (O hkawa, 1987). Armitage and Laushman (1990) reported that anemonetubers planted in N ovember and December produced higher quality flowers than those planted in J anuary and February due to cooler growing temperatures experienced during November and $\mathrm{De}$ cember planting versus J anuary and February planting. $\mathrm{H}$ arvest duration from first to last harvestable flower also decreased for plantings made after N ovember.

Delphinium is a perennial with a spike inflorescence; cool temperatures promote stem elongation (Dole and Wilkins, 1999b; G riffiths, 1995). D elphinium flowering is reduced at temperatures above $81^{\circ} \mathrm{F}\left(27^{\circ} \mathrm{C}\right.$ ) (Wang et al, 1997). Forcing temperature for flowering can be as low as $55^{\circ} \mathrm{F}(13$ ${ }^{\circ} \mathrm{C}$ ) (D ole and Wilkins, 1999b; $\mathrm{Nau}$, 1993b).

Cool temperatures are required for larkspur stem elongation. Six weeks at $36^{\circ} \mathrm{F}\left(2^{\circ} \mathrm{C}\right)$ has been reported to be most effective for flower initiation and development. It was also noted that larkspur stem elongation is reduced at $55^{\circ} \mathrm{F}\left(13^{\circ} \mathrm{C}\right)$ when given long days (D ole and Wilkins, 1999b).

N o published information isavailable on the specific cultural requirementsfor Lu pinushartwegi i. H owever, floral initiation and days to anthesis were reduced for blue lupine ( $L$. angustifoliusL.), rough-seeded lupine (L. consentini Guss.), and yellow lupine (L. luteusL.) when grown at 82/ $70^{\circ} \mathrm{F}\left(28 / 21^{\circ} \mathrm{C}\right)$ (day/ night) compared to $70 / 57^{\circ} \mathrm{F}\left(21 / 14^{\circ} \mathrm{C}\right.$ ) (day/ night) (Rahman and Gladstones, 1972).

'O regon Giants' is a pansy cultivar with larger flowersand longer stems than cultivars used as bedding plants. $\mathrm{H}$ igh temperatures [ $77^{\circ} \mathrm{F}\left(25^{\circ} \mathrm{C}\right)$ ] promote internode elongation and faster growth ratesfor pansies (Pearson et al., 1995). When pansies are produced at cool temperatures, a slow growth rateisachieved allowing a long duration for flower development, thus creating a large flower. Pansies should be grown at 39 to $55^{\circ} \mathrm{F}\left(4\right.$ to $\left.13^{\circ} \mathrm{C}\right)$ to reduce internode elongation and ensure high quality flowers (Post, 1949).

Growth rates for snapdragon are highest when mature plants are grown at 55 to $61^{\circ} \mathrm{F}$ ( 13 to $16^{\circ} \mathrm{C}$ ); media temperatures above $79{ }^{\circ} \mathrm{F}\left(26^{\circ} \mathrm{C}\right)$ increase days to anthesis (Dole and Wilkins, 1999a; Wai and Newman, 1992). H owever, M iller (1962) noted snapdragon's growth rate is slower at

T able 1. Direct and indirect expenses of unheated and minimally heated greenhouse production of anemone, delphinium, larkspur, lupine, pansy, snapdragon, stock, and sunflower cut flowers.

\begin{tabular}{|c|c|c|c|c|}
\hline \multirow{3}{*}{$\begin{array}{l}\text { Expense } \\
\text { category }\end{array}$} & \multicolumn{2}{|c|}{ Year 1} & \multicolumn{2}{|c|}{ Year 2} \\
\hline & \multicolumn{4}{|c|}{ Minimum greenhouse temp ${ }^{2}$} \\
\hline & Unheated & $55^{\circ} \mathrm{F}$ & $36^{\circ} \mathrm{F}$ & $50^{\circ} \mathrm{F}$ \\
\hline & \multicolumn{4}{|c|}{ D irect expenses $\left(\$ / 9 \mathrm{ft}^{2}\right)^{\mathrm{y}}$} \\
\hline $\mathrm{H}$ eating & 0.00 & 5.44 & 2.91 & 4.36 \\
\hline Labor (manager) & 7.50 & 7.50 & 7.50 & 7.50 \\
\hline Labor (production) & 2.14 & 2.14 & 2.14 & 2.14 \\
\hline \multirow[t]{2}{*}{ Labor (postharvest) } & 3.57 & 3.57 & 3.57 & 3.57 \\
\hline & \multicolumn{4}{|c|}{ Indirect expenses $\left(\$ / 9 \mathrm{ft}^{2}\right)$} \\
\hline Fertilizer & 0.24 & 0.24 & 0.22 & 0.22 \\
\hline Production supplies & 3.98 & 3.98 & 3.98 & 3.98 \\
\hline Postharvest supplies & 1.79 & 1.79 & 1.79 & 1.79 \\
\hline Water & 0.21 & 0.21 & 0.16 & 0.16 \\
\hline Electricity & 0.08 & 0.08 & 0.34 & 0.34 \\
\hline Property mortgage & 2.63 & 2.63 & 2.45 & 2.45 \\
\hline Polyethylene glazing & 0.49 & 0.49 & 0.46 & 0.46 \\
\hline Greenhouse & 1.85 & 1.85 & 1.72 & 1.72 \\
\hline $\mathrm{M}$ iscellaneous ${ }^{\mathrm{x}}$ & 1.89 & 1.89 & 1.76 & 1.76 \\
\hline Total & 24.26 & 29.70 & 27.24 & 28.69 \\
\hline
\end{tabular}

z36 ${ }^{\circ} \mathrm{F}=2{ }^{\circ} \mathrm{C}, 50^{\circ} \mathrm{F}=10^{\circ} \mathrm{C}, 55^{\circ} \mathrm{F}=13^{\circ} \mathrm{C}$.

y $\$ 1.00 / 9 \mathrm{ft}^{2}=\$ 1.20 / \mathrm{m}^{2}$.

xI ncludes tractor, implements, vehicle, auto maintenance, and transportation expenses. 
$50^{\circ} \mathrm{F}\left(10^{\circ} \mathrm{C}\right)$ than at $77^{\circ} \mathrm{F}\left(25^{\circ} \mathrm{C}\right)$.

A great diversity in flower response occurs among stock cultivars. High temperatures [ $61^{\circ} \mathrm{F}\left(16^{\circ} \mathrm{C}\right)$ or higher] delay flowering in most cultivars (Cockshull, 1985). H eide (1963) reported that stem elongation was greatest and visible bud was reached in fewest days when plants were grown with long days ( 9 h or longer) at 54 to $61^{\circ} \mathrm{F}\left(12\right.$ to $\left.16^{\circ} \mathrm{C}\right)$.

$\mathrm{H}$ igh growth rates for sunflower are achieved when grown at 65 to 75 ${ }^{\circ} \mathrm{F}\left(18\right.$ to $24^{\circ} \mathrm{C}$ ) and growth rates are reduced at lower temperatures (Armitage, 1993; Schuster, 1985). Under proper growing conditions, sunflowers can reach anthesis in as few as 8 weeks after sowing seeds ( $R$. Sterkel, personal communication).

The objective of this study was to determine if anemone, delphinium, larkspur, lupine, pansy, snapdragon, stock, and sunflower could be economically grown in unheated, minimally heated, or heated greenhouses to produce high quality cut flowers during winter months.

\section{Materials and methods}

Delphinium 'C asa Blanca', larkspur 'Giant Imperial Mix', lupine 'B right Gems', pansy 'O regon Giant', snapdragon 'Animation M ix', and stock 'C heerful White' seeds were sown in seed flats [ 29 inches $^{3}\left(475 \mathrm{~cm}^{3}\right) /$ cell] containing a peat-lite commercial medium (Redi Earth, Scotts-Sierra H orticultural Products Company, $M$ arysville, $O$ hio). At the appearance of the first true leaves, plants were transplanted into bedding plant flats [ 3 inches $^{3}\left(49 \mathrm{~cm}^{3}\right) /$ cell] using a commercial peat-based root substrate (BM 1, Berger Peat Moss, SaintM odeste, Q uebec). After establishment in flats, plants were transplanted into raised sandy loam ground beds in double-layered polyethylene-covered greenhouses. Anemone tubers were kept at $41 \pm 1^{\circ} \mathrm{F}\left(5 \pm 0.6^{\circ} \mathrm{C}\right)$ for $30 \mathrm{~d}$, until the other specieswere planted, to provide the floral initiation and development cold treatment (O hkawa, 1987). Tubers were planted 6 inches $(15 \mathrm{~cm})$ from the soil surface to the bottom of the tuber. L arkspur, lupine, pansy, and snapdragon plants were spaced at $3 \times 6$ inches $(8 \times 15 \mathrm{~cm})$ and anemone, del phinium, and stock plants at $6 \times 6$ inches. In year 2 , delphinium and pansy were eliminated from the study due to low consumer demand and sunflower, spaced at $6 \times 12$ inches $(15 \times 30 \mathrm{~cm})$, was added.

$D$ ata collected included number of stems harvested, harvest date, stem length, flower sales price, and direct and indirect expenses (T able1). Stems possessing high retail market qualities (sufficient stem length, diameter, flower size, and color) were harvested and sold direct to retail florists. Profit or loss was calculated as sales price minus direct and indirect expenses (Table 1). Results were expressed in profit or loss per sample area, about 9 $\mathrm{ft}^{2}\left(0.84 \mathrm{~m}^{2}\right)$ per species sample. 0 ther data collected included daily air and soil temperatures. The design was a modified split plot. The greenhouses were the main plots and there were four samples of 72 plants/ sample for larkspur, lupines, pansy and snapdragon; 36 plants/ sample for anemone, delphinium, and stock; and 18 plants/ sample for sunflower. D ata were analyzed by general linear model procedure(SASI nstitute, Cary, N.C.).
In year 1 , plants were grown in two greenhouses: 1) unheated (ambient) with average daily high/ low temperatures of $84 / 48{ }^{\circ} \mathrm{F}\left(29 / 9{ }^{\circ} \mathrm{C}\right)$ and average soil temperature of $59^{\circ} \mathrm{F}$ ( 15 $\left.{ }^{\circ} \mathrm{C}\right)$; 2) heated with a minimum night temperature of $55^{\circ} \mathrm{F}\left(13^{\circ} \mathrm{C}\right)$, average daily high/ low temperatures of 84 / $59{ }^{\circ} \mathrm{F}\left(29 / 15^{\circ} \mathrm{C}\right)$ and average soil temperature of $63^{\circ} \mathrm{F}\left(17^{\circ} \mathrm{C}\right)$ (Fig. 1).

In year 2 , greenhouses were set at minimal night temperatures of either 36 or $50^{\circ} \mathrm{C}\left(2\right.$ or $\left.10^{\circ} \mathrm{C}\right)$. The $36^{\circ} \mathrm{F}$ greenhouse average daily high/low temperatures were $73 / 46{ }^{\circ} \mathrm{F}$ (23/ 8 ${ }^{\circ} \mathrm{C}$ ) with an average soil temperature of $57^{\circ} \mathrm{F}\left(14^{\circ} \mathrm{C}\right)$. The average daily high/ low temperatures for the $50{ }^{\circ} \mathrm{F}$ greenhouse were $77 / 54^{\circ} \mathrm{F}(25 / 12$ ${ }^{\circ} \mathrm{C}$ ) with an average soil temperature of $59^{\circ} \mathrm{F}\left(15^{\circ} \mathrm{C}\right)$ (Fig. 2).

\section{Results}

\section{Anemone 'J erusalem Mix'}

YeAR 1. Stems in the $55^{\circ} \mathrm{F}$ greenhouse were 0.6 inches $(1.5 \mathrm{~cm})$ longer

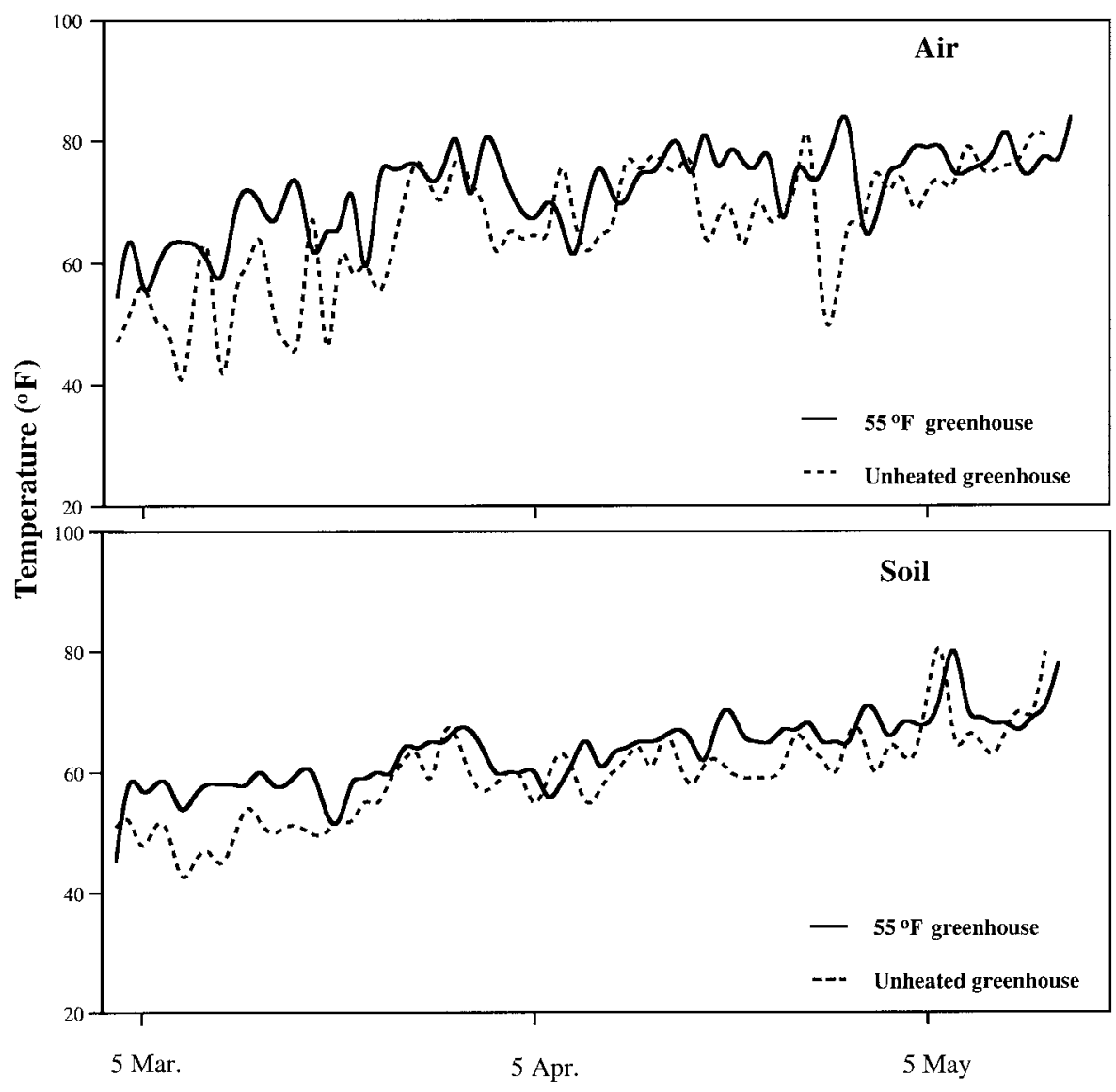

Hortlechnology • O ctober-D ecember 2000 10(4)

Fig. 1. Average daily greenhouse air and soil temperatures during year 1. Air thermometers were 18 inches $(45 \mathrm{~cm})$ above soil surface and soil temperature was recorded 5 inches $(13 \mathrm{~cm})$ below the surface; ${ }^{\circ} \mathrm{C}=5 / 9\left({ }^{\circ} \mathrm{F}-32\right)$ 


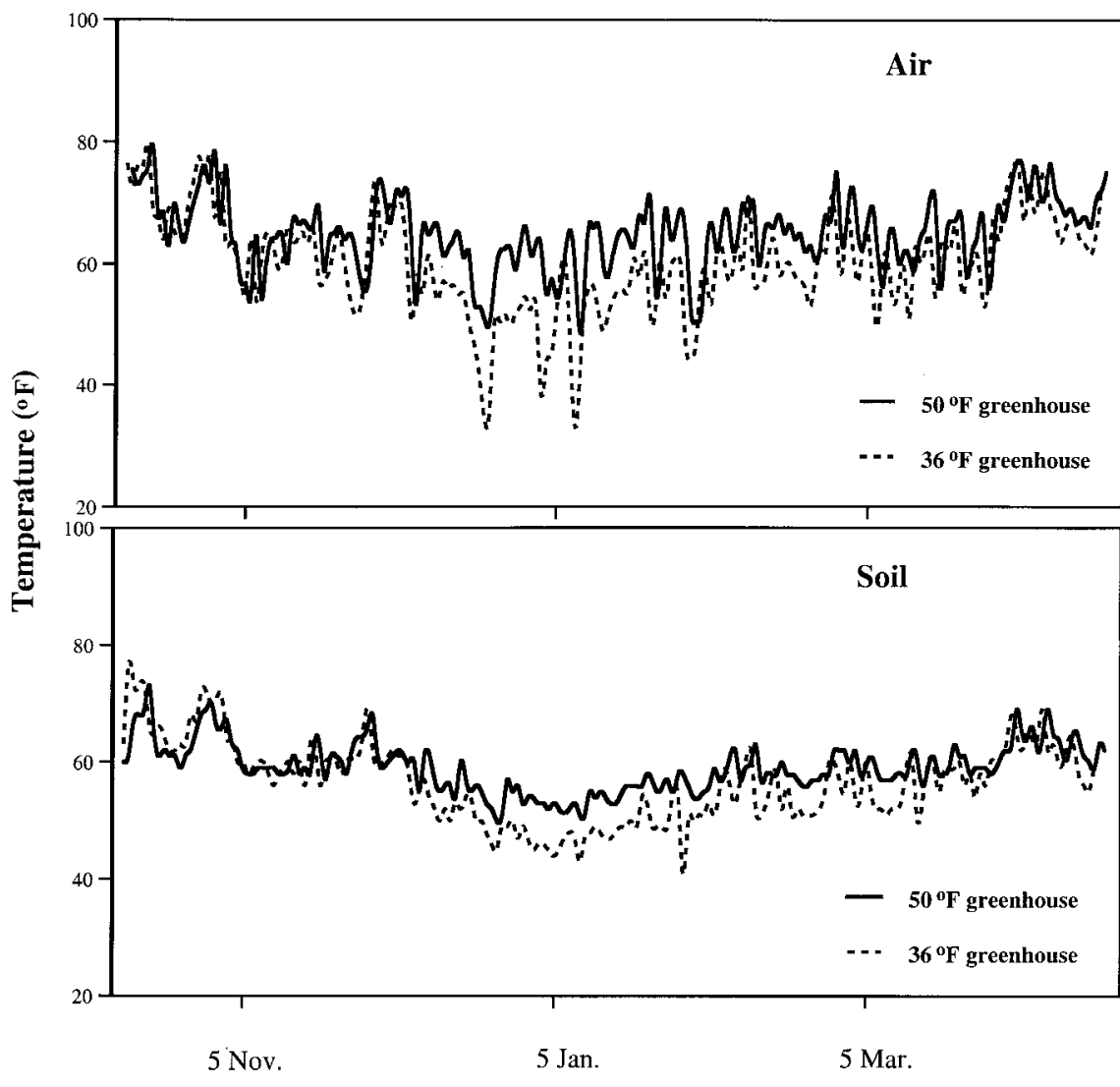

Date

Fig. 2. Average daily greenhouse air and soil temperatures during year 2. Air thermometers were 18 inches $(45 \mathrm{~cm})$ above soil surface and soil temperature was recorded 5 inches ( $13 \mathrm{~cm}$ ) below the surface; ${ }^{\circ} \mathrm{C}=5 / 9\left({ }^{\circ} \mathrm{F}-32\right.$ )

and were harvested $7 \mathrm{~d}$ earlier than the plants in the unheated greenhouse (Table 2). Anemone was not profitable when grown in either greenhouse due to spacing requirements for the tubers. H owever, the unheated greenhouse net loss/ sample was $\$ 13.50$ less than the $55^{\circ} \mathrm{F}$ greenhouse due to lack of heating expensesand increased stem yield.

Year 2. The $50{ }^{\circ} \mathrm{F}$ greenhouse reduced production time $15 \mathrm{~d}$ compared to the $36^{\circ} \mathrm{F}$ greenhouse (Table $3)$. H owever, the $36^{\circ} \mathrm{F}$ greenhouse stems were 2.6 inches $(6.6 \mathrm{~cm})$ longer than the $50^{\circ} \mathrm{F}$ greenhousestems. While neither greenhouse was profitable, the $36^{\circ} \mathrm{F}$ greenhouse net loss/ sample was $\$ 9.97$ less than the $50^{\circ} \mathrm{F}$ greenhouse due to reduced heating expenses. In both years, stem number was unaffected by treatments.

\section{Delphinium 'Casa Blanca'}

The unheated greenhouse stems were 2.0 inches $(5.1 \mathrm{~cm})$ longer than the $55^{\circ} \mathrm{F}$ greenhouse stems (T able 2 ).
Plants in the $55^{\circ} \mathrm{F}$ greenhouse had a shorter production time (122 d) than plantsin theunheated greenhouse ( 149 d). N either greenhouse was profitable for delphinium. $\mathrm{H}$ owever, the $55^{\circ} \mathrm{F}$ greenhouses net loss/ sample was $\$ 13.10$ less than the unheated greenhouse due to temperatures [ $21^{\circ} \mathrm{F}(-6$ $\left.{ }^{\circ} \mathrm{C}\right)$ ] which killed plants in the nonheated greenhouseand higher stem numbers in the 55 of greenhouse. D elphinium was not repeated the second year due to low stem production.

\section{Larkspur 'Giant Imperial Mix'}

Year 1. Theunheated greenhouse stemswere 5.3 inches $(13.5 \mathrm{~cm})$ longer than the $55^{\circ} \mathrm{F}$ greenhousestems ( $\mathrm{T}$ able 2 ). Production time in the unheated greenhouse was 9 d longer than the 55 ${ }^{\circ} \mathrm{F}$ greenhouse. L arkspur was not profitable when grown at either greenhouse temperature. However, the unheated greenhouse's net loss/ sample was $\$ 3.29$ less than the $55^{\circ} \mathrm{F}$ greenhousedueto no heating expenses.
Year 2. Stems in the $50^{\circ} \mathrm{F}$ greenhouse were 2.9 inches $(7.4 \mathrm{~cm})$ longer and production time was $18 \mathrm{~d}$ shorter compared to the $36^{\circ} \mathrm{F}$ greenhouse (Table 3). Both greenhouses were profitable with a net profit/ samples of $\$ 26.42$ for the $36^{\circ} \mathrm{F}$ greenhouse compared to $\$ 23.21$ profit or sample for the $50{ }^{\circ} \mathrm{F}$ greenhouse. In both years, stem number was unaffected by treatments.

\section{Lupine 'Bright Gems'}

YeAR 1. Stem length and production time were not significantly different between the plantsin the unheated and $55^{\circ} \mathrm{F}$ greenhouses (T able2). Plants in the $55^{\circ} \mathrm{F}$ greenhouse produced 26 more stems/ samples than in the unheated greenhouse. Both greenhouses were profitable with the $55^{\circ} \mathrm{F}$ greenhouse profiting $\$ 21.71$ / sample compared to the $\$ 5.26$ unheated greenhouse profit/ sample. Greater profits from the $55^{\circ} \mathrm{F}$ greenhouse can be attributed to greater stem numbers produced compared to the unheated greenhouse.

Year 2. The $36{ }^{\circ} \mathrm{F}$ greenhouse stems were 2.2 inches $(5.6 \mathrm{~cm})$ longer than the $50^{\circ} \mathrm{F}$ greenhouse stems ( $\mathrm{T}$ able 3). The $50^{\circ} \mathrm{F}$ greenhouse plantsyielded 41 more stems/ sample and had a $22 \mathrm{~d}$ shorter production time compared to the $36^{\circ} \mathrm{F}$ greenhouse. O nly the $50{ }^{\circ} \mathrm{F}$ greenhouse was profitable for lupine yielding a $\$ 24.59$ profit/ sample due to increased stem numbers compared to a loss/ sample of $\$ 3.61$ for the $36^{\circ} \mathrm{F}$ greenhouse.

\section{Pansy 'Oregon Giant'}

Stem lengthsand production time did not significantly differ between the $55^{\circ} \mathrm{F}$ and unheated greenhouses ( $\mathrm{T}$ able $2)$. Pansy was profitably grown in the unheated greenhouse, netting $\$ 6.28 /$ sample dueto no heating expenses and 37 more stems compared to the $55^{\circ} \mathrm{F}$ loss/ sample of $\$ 13.09$. Pansy was not repeated in the second year due to minimal consumer demand.

\section{Snapdragon 'Animation Mix'}

Year 1. Stems in the unheated greenhouse were 6.1 inches $(15.5 \mathrm{~cm})$ longer than stems from the $55{ }^{\circ} \mathrm{F}$ greenhouse (T able 2). The unheated greenhouse produced 42 more stems in 10 fewer days than $55^{\circ} \mathrm{F}$ greenhouse. Plants in the unheated greenhouse netted a $\$ 22.80$ profit/ sample due to increased stem number and 
lower heating expenses compared to the $55^{\circ} \mathrm{F}$ greenhouse which lost $\$ 7.16 /$ sample.

Year 2. The $36{ }^{\circ} \mathrm{F}$ greenhouse stemswere 5.4 inches $(13.5 \mathrm{~cm})$ longer than the $50^{\circ} \mathrm{F}$ greenhouse stems. The $50^{\circ} \mathrm{F}$ greenhouse plants produced the most stems (117) in the shortest production time (176 d) (Table 3). Both greenhouseswere profitablewith a net profit/ sample of $\$ 39.75$ for the $50^{\circ} \mathrm{F}$ greenhousedueto increased stem number compared to $\$ 31.84$ profit/ sample for the $36{ }^{\circ} \mathrm{F}$ greenhouse.

\section{Stock 'Cheerful White'}

YEAR 1. The unheated greenhouse stems were 5.6 inches $(14.2 \mathrm{~cm})$ longer than the $55^{\circ} \mathrm{F}$ greenhousestems ( $\mathrm{T}$ able
2). Production time in the $55^{\circ} \mathrm{F}$ greenhouse was $6 \mathrm{~d}$ less than that in the unheated greenhouse. While stock was not profitable when grown at either greenhouse temperature, the unheated greenhouse net loss/ sample was $\$ 4.12$ less than the $55^{\circ} \mathrm{F}$ greenhouse due to heating expenses in the $55^{\circ} \mathrm{F}$ greenhouse.

Year 2. The $36{ }^{\circ} \mathrm{F}$ greenhouse stems were 6.0 inches $(15.3 \mathrm{~cm})$ longer and production time $14 \mathrm{~d}$ longer compared to the $50{ }^{\circ} \mathrm{F}$ greenhouse plants (Table3). N either greenhousewasprofitable for stock. In both years, stem number was unaffected by treatments.

\section{Sunflower 'Sunrich Or- ange'}

The $36^{\circ} \mathrm{F}$ greenhousestemswere 3.4 inches $(8.6 \mathrm{~cm}$ ) longer than the 50 ${ }^{\circ} \mathrm{F}$ greenhouse stems (Table 3 ). The $50{ }^{\circ} \mathrm{F}$ greenhouse reduced production time by $28 \mathrm{~d}$ compared to the $36^{\circ} \mathrm{F}$ greenhouse. Though neither greenhouse was profitable, the $36^{\circ} \mathrm{F}$ greenhouse net loss/ sample was $\$ 1.19$ less than the $50{ }^{\circ} \mathrm{F}$ greenhouse due to greater heating expenses in the $50{ }^{\circ} \mathrm{F}$ greenhouse. Stem numberswere unaffected by greenhouse temperatures.

\section{Discussion}

In year 1 , the air temperature inside the unheated greenhouse averaged $3.2^{\circ} \mathrm{F}\left(1.8^{\circ} \mathrm{C}\right)$ higher than the outside air temperature and the inside soil temperature $6.7^{\circ} \mathrm{F}\left(3.7^{\circ} \mathrm{C}\right)$ higher

Table 2. Effect of unheated (ambient) or $55^{\circ} \mathrm{F}\left(13^{\circ} \mathrm{C}\right)$ minimum night temperatures on stem length and production time of anemone, delphinium, larkspur, lupine, pansy, snapdragon and stock cut flowers during year 1 . M eans are an average of four samples per treatment for number of stems harvested and total net profit or loss and $\mathbf{3 6}$ to 72 plants per sample for stem length and production time.

\begin{tabular}{|c|c|c|c|c|}
\hline $\begin{array}{l}\text { Night } \\
\text { temp }\end{array}$ & $\begin{array}{c}\text { Stems } \\
\text { harvested } \\
\text { (no.) }\end{array}$ & $\begin{array}{c}\text { Stem } \\
\text { length } \\
\text { inches }(\mathrm{cm})\end{array}$ & $\begin{array}{c}\text { Production } \\
\text { time } \\
\text { (days) } \\
\end{array}$ & $\begin{array}{c}\text { Total net } \\
\text { profit/loss } \\
\text { (\$) }\end{array}$ \\
\hline $\begin{array}{l}\text { U nheated } \\
55^{\circ} \mathrm{F}\left(13^{\circ} \mathrm{C}\right) \\
\text { Significance }\end{array}$ & $\begin{array}{l}41 \\
36 \\
\text { NS }\end{array}$ & $\begin{array}{c}\text { Anemo } \\
8.8(22.4) \\
9.4(23.9) \\
0.0312^{\mathrm{x}}\end{array}$ & $\begin{array}{c}\text { em M ix } \\
113 \\
106 \\
0.0001\end{array}$ & $\begin{array}{l}-26.92 \\
-40.42 \\
0.0001\end{array}$ \\
\hline $\begin{array}{l}\text { U nheated } \\
55^{\circ} \mathrm{F}\left(13^{\circ} \mathrm{C}\right) \\
\text { Significance }\end{array}$ & $\begin{array}{c}8 \\
42 \\
0.0008\end{array}$ & $\begin{array}{c}\text { D elphi } \\
26.6(67.6) \\
24.6(62.5) \\
0.0022\end{array}$ & $\begin{array}{c}\text { Blanca } \\
149 \\
122 \\
0.0001\end{array}$ & $\begin{array}{r}-17.52 \\
-4.42 \\
0.0001\end{array}$ \\
\hline $\begin{array}{l}\text { U nheated } \\
55^{\circ} \mathrm{F}\left(13^{\circ} \mathrm{C}\right) \\
\text { Significance }\end{array}$ & $\begin{array}{l}35 \\
37 \\
\text { N S }\end{array}$ & $\begin{array}{c}\text { Larkspur } \\
34.3(87.1) \\
29.0(73.7) \\
0.0001\end{array}$ & $\begin{array}{c}\text { perial M ix } \\
151 \\
142 \\
0.0001\end{array}$ & $\begin{array}{l}-0.71 \\
-4.00 \\
0.0001\end{array}$ \\
\hline $\begin{array}{l}\text { U nheated } \\
55^{\circ} \mathrm{F}\left(13^{\circ} \mathrm{C}\right) \\
\text { Significance }\end{array}$ & $\begin{array}{c}53 \\
79 \\
0.0290\end{array}$ & $\begin{array}{c}\text { Lupi } \\
19.3(49.0) \\
19.4(49.3) \\
\text { NS }\end{array}$ & $\begin{array}{c}\text { Gems } \\
122 \\
122 \\
\text { NS }\end{array}$ & $\begin{array}{l}5.26 \\
21.71 \\
0.0001\end{array}$ \\
\hline $\begin{array}{l}\text { U nheated } \\
55^{\circ} \mathrm{F}\left(13^{\circ} \mathrm{C}\right) \\
\text { Significance }\end{array}$ & $\begin{array}{c}67 \\
30 \\
0.0050\end{array}$ & $\begin{array}{c}\text { Pans } \\
7.5(19.1) \\
7.0(17.8) \\
\text { NS }\end{array}$ & $\begin{array}{c}\text { Giant } \\
108 \\
105 \\
\text { NS }\end{array}$ & $\begin{array}{c}6.28 \\
-13.09 \\
0.0001\end{array}$ \\
\hline $\begin{array}{l}\text { U nheated } \\
55^{\circ} \mathrm{F}\left(13^{\circ} \mathrm{C}\right) \\
\text { Significance }\end{array}$ & $\begin{array}{c}74 \\
32 \\
0.0096\end{array}$ & $\begin{array}{c}\text { Snapdras } \\
23.8(60.5) \\
17.7(45.0) \\
0.0001\end{array}$ & $\begin{array}{c}\text { ation M ix } \\
145 \\
155 \\
0.0001\end{array}$ & $\begin{array}{l}22.80 \\
-7.16 \\
0.0001\end{array}$ \\
\hline $\begin{array}{l}\text { U nheated } \\
55^{\circ} \mathrm{F}\left(13^{\circ} \mathrm{C}\right) \\
\text { Significance }\end{array}$ & $\begin{array}{l}35 \\
36 \\
\text { NS }\end{array}$ & $\begin{array}{c}\quad \text { Stock } \\
20.6(52.3) \\
15.0(38.1) \\
0.0001\end{array}$ & $\begin{array}{l}\text { White } \\
\qquad \begin{array}{l}117 \\
111 \\
0.0001\end{array}\end{array}$ & $\begin{array}{l}-2.58 \\
-6.70 \\
0.0001\end{array}$ \\
\hline
\end{tabular}

zPlants were sown on $15 \mathrm{Dec} .1997$.

ySales expenses $=$ profit for about $9 \mathrm{ft}^{2}\left(0.84 \mathrm{~m}^{2}\right)$.

$\mathrm{xP}>\mathrm{F}$.

Ns N onsignificant. 
than the outside soil temperature. $\mathrm{H}$ owever, a minimum temperature of $22^{\circ} \mathrm{F}\left(-6^{\circ} \mathrm{C}\right)$ occurred in the unheated greenhouse one night when the outside temperature dropped to $16^{\circ} \mathrm{F}\left(-9^{\circ} \mathrm{C}\right)$. Due to soil heating and wind protection by the greenhouse, air and soil temperatures inside the greenhouse remained above freezing if outside temperatures did not go below $30{ }^{\circ} \mathrm{F}\left(-1{ }^{\circ} \mathrm{C}\right.$ ) (data not presented).

The extreme low temperatures of $22^{\circ} \mathrm{F}\left(-6^{\circ} \mathrm{C}\right)$ experienced in the unheated greenhouse greatly reduced harvestable stems for delphinium and lupine (Table 2). The low temperatures were much less than 55 to $61^{\circ} \mathrm{F}$ (13 to $16{ }^{\circ} \mathrm{C}$ ) which promote flower development for delphinium and flower initiation for rough-seeded lupine (L. consentinii) (H olcomb and Beatti, 1988; Rahman and G ladstones,
1972). M any delphinium plants were killed and did not produce stems. Lupine plants were damaged by the cold temperatures, but new growth after the damaging freeze was unaffected. Delphinium and lupine harvestable stem numbers increased when grown in the $55^{\circ} \mathrm{F}$ compared to the $36^{\circ} \mathrm{F}$ greenhouse.

Anemone, pansy, and snapdragon yielded more harvestable stems and delphinium, larkspur, snapdragon, and stock produced longer stems when grown in the unheated compared to the $55^{\circ} \mathrm{F}$ greenhouse. The unheated greenhouse had a greater positive difference in day and night temperatures (DIF) which has been shown to promote stem elongation (Erwin et al., 1989a, 1989b). O hkawa(1987) noted that anemone produces higher quality and number of stems at cool night temperatures [ 41 to $50{ }^{\circ} \mathrm{F}$ ( 5 to 10 $\left.{ }^{\circ} \mathrm{C}\right)$ ]. In addition, delphinium, larkspur, snapdragon, and stock produce high quality flowers when grown at 45 to $61{ }^{\circ} \mathrm{F}$ ( 7 to $16{ }^{\circ} \mathrm{C}$ ) (Dole and Wilkins, 1999a, 1999b; $\mathrm{N}$ au, 1993a, 1993b).

Anemonestemswerelonger when grown in the $55^{\circ} \mathrm{F}$ greenhouse compared to the unheated greenhouse. The $55^{\circ} \mathrm{F}$ greenhouse also reduced production time for anemone, delphinium, larkspur, and stock (Table 2). Karlsson (1997) and Pearson et al. (1995) obtained similar results with anemone and pansy.

The $55^{\circ} \mathrm{F}$ greenhouse's total net loss/ sample for all species combined [ $63 \mathrm{ft}^{2}\left(6 \mathrm{~m}^{2}\right)$ ] was $\$ 54.08$ compared to the unheated greenhouse'stotal net loss/ sample for all species combined of \$13.39 (Table 2). G reater net loss in the $55^{\circ} \mathrm{F}$ compared to thenonheated greenhouse was due to higher heating

Table 3. E ffect of 36 or $50{ }^{\circ} \mathrm{F}\left(2\right.$ or $\left.10^{\circ} \mathrm{C}\right)$ minimum night temperatures on stem length and production time of anemone, larkspur, lupine, snapdragon, stock, and sunflower cut flowers in year 2. M eans are an average of four samples per treatment for number of stems harvested and total net profit or loss and 18 to 72 plants per sample for stem length and production time.

\begin{tabular}{|c|c|c|c|c|}
\hline $\begin{array}{l}\text { Night } \\
\text { temp }\end{array}$ & $\begin{array}{c}\text { Stems } \\
\text { harvested } \\
\text { (no.) }\end{array}$ & $\begin{array}{c}\text { Stem } \\
\text { length } \\
\text { inches }(\mathrm{cm})\end{array}$ & $\begin{array}{l}\text { Production } \\
\text { time }{ }^{2} \\
\text { (days) }\end{array}$ & $\begin{array}{c}\text { Total net } \\
\text { profit-loss } \\
\text { (\$) }\end{array}$ \\
\hline $\begin{array}{l}36^{\circ} \mathrm{F}\left(2^{\circ} \mathrm{C}\right) \\
50^{\circ} \mathrm{F}\left(10^{\circ} \mathrm{C}\right) \\
\text { Significance }\end{array}$ & $\begin{array}{l}71 \\
57 \\
\text { NS }\end{array}$ & $\begin{array}{c}\text { Anemc } \\
20.4(51.8) \\
17.8(45.2) \\
0.0001\end{array}$ & $\begin{array}{c}\text { M ix } \\
64 \\
49 \\
0.0001\end{array}$ & $\begin{array}{l}-13.49 \\
-23.46 \\
0.0001\end{array}$ \\
\hline $\begin{array}{l}36^{\circ} \mathrm{F}\left(2{ }^{\circ} \mathrm{C}\right) \\
50^{\circ} \mathrm{F}\left(10^{\circ} \mathrm{C}\right) \\
\text { Significance }\end{array}$ & $\begin{array}{l}88 \\
83 \\
\text { NS }\end{array}$ & $\begin{array}{c}\text { Larkspur } \\
17.4(44.2) \\
20.3(51.6) \\
0.0001\end{array}$ & $\begin{array}{c}\text { erial M ix } \\
114 \\
96 \\
0.0001\end{array}$ & $\begin{array}{l}26.42 \\
23.21 \\
0.0001\end{array}$ \\
\hline $\begin{array}{l}36^{\circ} \mathrm{F}\left(2^{\circ} \mathrm{C}\right) \\
50^{\circ} \mathrm{F}\left(10^{\circ} \mathrm{C}\right) \\
\text { Significance }\end{array}$ & $\begin{array}{c}48 \\
89 \\
0.0226\end{array}$ & $\begin{array}{c}\quad \text { Lupi } \\
31.2(79.2) \\
29.0(73.7) \\
0.0036\end{array}$ & $\begin{array}{l}168 \\
146 \\
0.0001\end{array}$ & $\begin{array}{r}-3.61 \\
24.59 \\
0.0001\end{array}$ \\
\hline $\begin{array}{l}36^{\circ} \mathrm{F}\left(2^{\circ} \mathrm{C}\right) \\
50^{\circ} \mathrm{F}\left(10^{\circ} \mathrm{C}\right) \\
\text { Significance }\end{array}$ & $\begin{array}{c}102 \\
117 \\
0.0206\end{array}$ & $\begin{array}{c}\text { Snapdra } \\
35.8(90.9) \\
30.4(77.2) \\
0.0001\end{array}$ & $\begin{array}{c}\text { tion } \mathrm{M} \text { ix } \\
181 \\
176 \\
0.0001\end{array}$ & $\begin{array}{l}31.84 \\
39.75 \\
0.0001\end{array}$ \\
\hline $\begin{array}{l}36^{\circ} \mathrm{F}\left(2^{\circ} \mathrm{C}\right) \\
50^{\circ} \mathrm{F}\left(10^{\circ} \mathrm{C}\right) \\
\text { Significance }\end{array}$ & $\begin{array}{l}55 \\
56 \\
\text { NS }\end{array}$ & $\begin{array}{c}\quad \text { Stock } \\
37.0(94.0) \\
31.0(78.7) \\
0.0001\end{array}$ & $\begin{array}{l}\text { White } \\
\qquad \begin{array}{l}175 \\
161 \\
0.0001\end{array}\end{array}$ & $\begin{array}{l}-1.42 \\
-1.61 \\
0.0001\end{array}$ \\
\hline $\begin{array}{l}36^{\circ} \mathrm{F}\left(2^{\circ} \mathrm{C}\right) \\
50^{\circ} \mathrm{F}\left(10^{\circ} \mathrm{C}\right) \\
\text { Significance }\end{array}$ & $\begin{array}{l}35 \\
33 \\
\text { NS }\end{array}$ & $\begin{array}{c}\text { Sunflon } \\
28.2(71.6) \\
24.8(63.0) \\
0.0053\end{array}$ & $\begin{array}{c}\text { O range } \\
154 \\
126 \\
0.0001\end{array}$ & $\begin{array}{l}-10.36 \\
-11.55 \\
0.0001\end{array}$ \\
\hline
\end{tabular}

zPlants were sown 15 Sept. 1998.

ySales expenses $=$ profit for about $9 \mathrm{ft}^{2}\left(0.84 \mathrm{~m}^{2}\right)$.

$\mathrm{xP}>\mathrm{F}$.

NsN onsignificant. 
expenses and lower stem numbers for anemone, pansy, and snapdragon. Lupine, pansy, and snapdragon were profitablein the unheated greenhouse. Lupine was the only species that was profitable in the $55^{\circ} \mathrm{F}$ greenhousedue to greater stem numbers which overcame heating expenses.

In year 2, both greenhouses were heated; thus, plants were protected from the extreme low temperatures. The $50{ }^{\circ} \mathrm{F}$ greenhouse reduced production time for anemone, larkspur, lupine, snapdragon, stock, and sunflower compared to the $36^{\circ} \mathrm{F}$ greenhouse (Table 3 ). $\mathrm{H}$ igh temperatures promotefast growing ratesand reduce production times. Similar results have been observed with anemone, lupine, pansy, snapdragon, and sunflower (Armitage, 1993; Karlsson, 1997; M iller, 1962; O hkawa, 1987; Pearson et al., 1995; Rahman and Gladstones, 1972; Schuster, 1985). The $50{ }^{\circ} \mathrm{F}$ greenhouse plants produced the most harvestablestems for lupine, and snapdragon and longest stems for larkspur which requires cool temperatures for stem elongation (Dole and Wilkins, 1999b).

L onger stems were measured for plants grown in the $36^{\circ} \mathrm{F}$ greenhouse for all cultivars except larkspur. The 36 - $\mathrm{F}$ greenhouse had a greater positive difference in day and night temperatures (DIF) which has been shown to promote stem elongation (Erwin et al., 1989a, 1989b). The cool temperatures also increased production time for all cultivars. $N$ et profit/ sample for all species combined [ $\left.54 \mathrm{ft}^{2}\left(5 \mathrm{~m}^{2}\right)\right]$ for the $50^{\circ} \mathrm{F}$ greenhousewas $\$ 50.93 \mathrm{com}$ pared to $\$ 29.38$ for the $36^{\circ} \mathrm{F}$ greenhouse due to more harvestable stems and reduced production time ( $\mathrm{T}$ able 3).

\section{Conclusion}

U nheated (ambient) winter greenhouse production is not recommended in areas with minimum temperatures of $29^{\circ} \mathrm{F}\left(-2^{\circ} \mathrm{C}\right)$ or lower due to possible freeze damage within the greenhouse. However, if only frost tolerant species such as larkspur, snapdragon, and stock aregrown, unheated greenhouses may be feasible in areas where the minimum temperature is less than $29^{\circ} \mathrm{F}\left(-2^{\circ} \mathrm{C}\right)$ as those species tolerated one night of $22^{\circ} \mathrm{F}\left(-6^{\circ} \mathrm{C}\right)$ with no negative effects.

In summary, minimally or unheated greenhouse special ty cut flower

Horllechnology O O ctober-D ecember 2000 10(4) production iseconomically feasiblefor some species such as anemone, larkspur, snapdragon, stock, and sunflower, with the use of unheated greenhouses restricted to cold tolerant species such as larkspur and stock. Other species such as delphinium and lupine are best produced in a warm greenhouse with a minimum night temperature of 50 ${ }^{\circ} \mathrm{F}\left(10^{\circ} \mathrm{C}\right)$.

\section{Literature cited}

Armitage, A.M . 1993. H elianthusannuus, p. 98-102. In: Specialty cut flowers. Varsity/ Timber Press, Portland, O re.

Armitage, A.M . and J.M . Laushman. 1990. Planting date, in-ground time affect cut flowers of A cidanthera, A nemone, Allium, Brodiaea, and Crocosmia. HortScience 25:1236-1238.

Cockshull, K.E. 1985b. M atthiola incana, p. 363-367. In: A.H . H alevy (ed.). H andbook of flowering. vol. 3. CRC Press, Boca Raton, Fla.

Dole, J.M . and H .F. Wilkins. 1999a. A ntirrhinum, p. 192-200. In: Floriculture: Principles and species. Prentice H all, U pper Saddle River, N.J .

Dole, J.M . and H .F. Wilkins. 1999b. Delphinium, p. 566-568. In: Floriculture: Principles and species. Prentice H all, U pper Saddle River, N.J .

Erwin, J.E., R.D. H eins, R. Berghage, and W. Carlson. 1989a. H ow can temperatures be used to control plant stem elongation? M inn. State Florist Bul. 38(3):1-5.

Erwin, J.E., R.D. H eins, and M.G. Karlsson. 1989b. Thermomorphogenesis in Lilium longiflorum. Amer.J . Bot. 76:4752.

Griffiths, M. 1995. Royal H orticultural Society index of garden plants. Timber Press. Portland, O re.

Holcomb, E.J and D.J. Beattie. 1988. Effect of growth retardants on perennials. Res. R pt. Bedding Plant Foundation 32:14.

Karlsson, M . 1997. Flowering response of A nemone coronaria to photoperiod and temperature. $\mathrm{H}$ ortScience 32:466 (abstr.).

M iller, R.O. 1962. Variations in optimum temperature of snapdragon depending on plant size. Proc. Amer. Soc. H ort. Sci. 81:535-543.

$\mathrm{Nau}, \mathrm{J}$. 1993a. Cut flowers, p. 66-81. In: Ball culture guide, the encyclopedia of seed germination. 2nd ed. Ball Publishing, Batavia, III.

N au, J. 1993b. Perennials, p. 82-111. In:
Ball culture guide, The encyclopedia of seed germination, 2nd ed. Ball Publishing, Batavia, III.

O hkawa, K. 1987. Growth and flowering of A nemone coronaria L. 'de Caen'. Acta H ort. 205:159-168.

Pearson, S., A. Parker, S.R. Adams, P. $H$ adley, and D.R. M ay. 1995. The effects of temperature on the flower size of pansy (Viola xwittrockiana Gams). J. H ort. Sci. 70:183-190.

Post, K. 1949. Viola tricolor and Viola cornuta; Viola odorata, p. 839-845. In: Florist crop production and marketing. O range J udd Publishing, N ew York.

Rahman, M.S. and F.S. Gladstone. 1974. Effectsof temperatureand photoperiod on flowering and yield components of lupin genotypes in the field. Austral. J. Expt. Agr. Animal H usbandry 14:205-213.

Sakai, A. 1960. The frost-hardiness of bulbs and tubers. J. H ort. Assn. Jpn. 29:233238.

Sakai, A. and F. Yoshie. 1984. Freezing tolerance of ornamental bulbs and corms. J. Jpn. Soc. H ort. Sci. 52:445-449.

Schuster, W.H ., 1985. H dianthusannuus, p. 98-121. In: A.H . H alevy (ed.). H andbook of flowering. vol. 3. CRC Press, Boca Raton, Fla.

Wai, K.S. and S.E. N ewman. 1992. Air and root-zone temperatures influence growth and flowering of snapdragons. H ortScience 27:796-798.

Wang, S.-Y., R.D. H eins, W.H . Carlson, and A.C. C ameron. 1997. E ffect of forcing temperature on flowering of four herbaceous perennial species. HortScience 32:501 (abstr.). 